\title{
Iowa's First Balloon Ascension
}

\author{
Ann Holtgren Pellegreno
}

DURING THE third Iowa State Fair, held at Muscatine in 1856, the balloon Hercules, owned by Silas M. Brooks, soared skyward in what was probably the first manned balloon ascension in the state. Sixty-two years had passed between the first public demonstration of an unmanned hot-air balloon by the Montgolfier Brothers at Annonay, France, on June 5, 1783, and a similar event in Iowa. For the Burlington Fourth of July celebration in 1845 an unmanned balloon was sent aloft.

It made one of the grandest ascensions we ever saw. It kept in sight about three quarters of an hour bearing a westerly direction, and we have not heard from it since. ${ }^{1}$

On August 7, 1783, the first ascension of a hydrogen-filled balloon was made by a Professor Charles in Paris, an event witnessed by Benjamin Franklin. The science of both hot-air and hydrogen ballooning gradually moved throughout Europe. Then, on June 24, 1784, about a year after the first Montgolfier balloon demonstration, thirteen-year-old Edward Warren of Baltimore, Maryland, became the first American to ascend in a balloon. This first documented manned ascension in this country occurred in a Montgolfier type balloon. Young Warren

${ }^{1}$ Burlington Hawk-Eye, July 10, 1845. 
climbed into the basket beneath the balloon, which was tethered, and the rope was let out. He ascended in the balloon, waving his hat and behaving with the "steady Fortitude of an Old Voyager." 2 After the balloon was hauled to earth again, some in the audience rewarded him with money.

The first manned balloon ascension and aerial voyage in this country was made on January 9, 1793, when John Pierre Blanchard, the famous French aeronaut, ascended from Philadelphia -President George Washington among the spectators-and drifted some three quarters of an hour before landing in a field.

Gradually ballooning spread westward across the country. In 1835 Richard Clayton, who could not resist the temptation of duplicating the aerial feats he had witnessed in his native England, made the first ascension in Ohio. The first ascension in Illinois was made on July 4, 1855 by Professor Silas M. Brooks ${ }^{3}$ in a borrowed balloon. During the landing the anchor hook caught on a telegraph wire, the basket fell with the aeronaut in it, and the big gas bag sailed off in an easterly direction. Unhurt in spite of his hard fall, Brooks declared the borrowed balloon unsafe, had one built to his specifications, and during the next few years made ascensions in many communities.

Fifteen thousand people had gathered in Muscatine for this third State Fair to view livestock, fruits and vegetables, fine and domestic arts, and Professor Brook's new balloon, Hercules, which had been well advertised. Both Muscatine newspapers carried notices of the big event which was to begin at 1:30 P.M. on Thursday, October 9, 1856. It was billed as "entertainment with a very heavy expense" and "the greatest novelty that has ever visited this city." 4

The ascension demanded the work of many and the acquisition of materials to make the hydrogen. By Tuesday, apparatus and paraphernalia had already begun arriving. A

${ }^{2}$ Maryland Journal and Baltimore Advertiser, June 25, 1784.

${ }^{3}$ The title Professor, which lent a certain amount of prestige, was taken by early balloonists, especially during the 1800 s since the practice of aerostation was in its infancy and considered to be a science undertaken only by experienced aeronauts.

${ }^{4}$ Muscatine Daily Evening Enquirer, October 6, 1856. 
huge covered tub was brought in sections, assembled, and connected by pipes to other mysterious looking receptacles. Large quantities of ice were ordered for packing around the unit when the gas was being generated. By Thursday noon the twelve-foot canvas barrier which enclosed the audience was ready.

As usual, many were willing to pay the enterprising aeronaut and purchased entrance into the balloon yard, but an estimated several thousand remained outside, reasoning that as soon as the balloon rose, they could see it just as well.

Generating the hydrogen was a lengthy and expensive process. If the ascension occurred in a city where coal gas was used for illumination, the balloon could be inflated directly at the street pipe or gas works. In the country, however, another method was used. The drawback of using only hot air, as was done in many ascensions, was that the balloon remained aloft only until the air inside cooled, causing the balloon to descend. With hydrogen or coal gas, the aeronaut could make extended journeys, and by judiciously throwing ballast out or releasing some gas, could regulate the height of the balloon. Since hydrogen is one of the components of water and fourteen times lighter than air, it was desirable for ascensions in spite of its extreme flammability.

Professor Brooks supervised the filling of the huge covered tub with two thousand pounds of iron in the form of turnings, shavings, and clippings from a machine shop which were thus inexpensive and also suitable since they allowed a large surface of iron to be exposed. Several barrels of water were poured over these filings. This rusted the iron, robbing the water of its oxygen content and setting free the hydrogen. When the surface of the iron rusted over, the rust protected the surface so sulphuric acid was added to clean the iron surfaces so they could rust again, releasing the hydrogen, and setting in motion a cycle of iron, water, rust, hydrogen, sulphuric acid, more rust, and more hydrogen.

Mixing the sulphuric acid and water produced heat. If the balloon were filled with gas at a high temperature, the aeronaut would find himself with a half-filled balloon when the gas cooled. Consequently, the gas entering the balloon had to be cool so the quantity could be relied upon to remain constant 
throughout the ascension. Further, it had to be dry. Water vapor exited the generating unit with the hydrogen. Ice was packed around the generating unit to cool the gas and then the hydrogen and water vapor passed through a drying tube filled with calcium chloride which collected the moisture.

The Hercules consisted of a huge gas bag and a large strong net encompassing the bag from which cords were attached to the wicker basket of the aeronaut. The gas bag was made of well-varnished lightweight fabric to make it as airtight as possible. In the top of the gas bag was a valve actuated by a string which the aeronaut pulled to release gas when he wished to descend. A few yards of stout cord attached to a three-pronged hook served as an anchor in making the landing.

The gas bag was laid on the ground and the net eased over the upper part. Professor Brooks attached the connecting tube from the balloon to the generating unit and gradually hydrogen entered the gas bag. Finally the top began to rise. Men held the guy ropes so the balloon would stay in position. While the balloon filled, the professor addressed the audience, giving them a concise history of ballooning from the first ascension to the present time. "Ballooning as a science had attained its perfection," he said. "Man never can guide at will an instrument of flight like a balloon. He will need wings to enable him to travel against a current of air." 5

By 4:30 the top of the big yellow balloon had risen above the canvas wall. Professor Brooks stated he would not be making the ascension, but that a Mr. Leonard, a young man who had made five ascensions, desired to go up and he had consented to his doing so.

The balloon expanded and rose, tugging strongly at the sandbags attached to the net and at the guy ropes held by the men. Finally, the wicker basket was tied securely with the long cords from the net. The aeronaut placed sandbags totaling some sixty pounds into the basket for ballast and also a bag of feathers.

$\mathrm{Mr}$. Leonard climbed into the basket, the word was given, and the men stationed at the cords on all sides of the balloon let

${ }^{5}$ Muscatine Daily Joumal, October 11, 1856. 
go and steadied the wicker basket. The balloon, almost free, swayed to and fro, and then at release, rose steadily amid cheers from the spectators. Up and up it went, a thousand feet, then two thousand, then half a mile and a mile. It drifted on a northerly course, diminishing in size until it seemed to be but a motionless speck.

As the balloon rose, Mr. Leonard occasionally dropped a few feathers, just as a sailor drops a "log" in the water to gauge directions. If the balloon were rising and drifting, the feathers would appear to be left below and behind. If the balloon were descending, the feathers would appear to be rising. The aeronaut could thus control vertical motion, by pulling the cord to release gas if he wanted to descend. By throwing out handfuls of sand he could stop a descent and start going up again.

$\mathrm{Mr}$. Leonard drifted for three quarters of an hour before coming to earth in Cedar County, three miles north of Wilton and fifteen miles from Muscatine. He returned to Muscatine Friday morning on the 10:45 train, bringing the balloon with him, and thus beginning Iowa's entry into the era of balloons.

Following this ascension several internationally known balloonists and some Iowans made ascensions throughout the state. Interest in ballooning lagged, however, when aeroplanes began to appear in the state, but eventually revived. Now thousands of Iowans once again can gaze at the spectacle of balloons going up at the annual national competition held at Indianola every August. The balloon has never relinquished its hold on the imagination; whenever one soars skyward and drifts over the countryside, those who watch still stand in near silence, preoccupied by the big gas bags sailing silently above them. And this era began for Iowans that October day in Muscatine, 1856. 
Copyright of Annals of Iowa is the property of State of Iowa, by \& through the State Historical Society of Iowa and its content may not be copied or emailed to multiple sites or posted to a listserv without the copyright holder's express written permission. However, users may print, download, or email articles for individual use. 